\title{
ACADEMIC INTEGRITY AS AN ELEMENT OF THE SYSTEM OF EDUCATION QUALITY ASSURANCE
}

\section{Tytska Ya. O.}

\section{INTRODUCTION}

In the modern context of education reforming as a multicomponent phenomenon, adoption of updated legislation including the regulations related to the independent functioning of the education system, the priority belongs to the education quality insurance; generating public confidence in the system and educational institutions, education authorities; constant and consistent improvement of education quality; assistance to education establishments and other actors of educational activities in enhancing education quality. The task may be accomplished on the basis of effective and expedient use of all elements of the system of education quality assurance. Academic integrity is a newish concept for the legal framework, but it is not new for the use and practice of the educational institutions and applicants of different grade levels.

It stands to mention the recent raising interest of scholars in the clarification of the essence of academic integrity as well as individual aspects of its application, for examples, a collective paper "Academic integrity as a basis for the sustainable university development" (Kyiv, 2016) $)^{1}$, a collective monograph "Academic integrity: compliance challenges and priorities of extension among young researchers" (Dnipro, 2017) ${ }^{2}$, proceedings of III International scientific-practical conference of students and young researchers "Academic integrity of a student as a factor for civil society formation" (Chernivtsi, 2018) ${ }^{3}$ etc.

The relevance of the topic is due to the sound importance of academic integrity to guarantee and improve the education quality as well as the need to study the very legal aspect of establishing the general principles of academic integrity for their effective application.

\footnotetext{
${ }^{1}$ Академічна чесність як основа сталого розвитку університету / Міжнарод. благод. Фонд "Міжнарод. фонд. дослідж. освіт. Політики"; за заг. ред. Т. В. Фінікова, А. Є. Артюхова. Київ : Таксон, 2016. 234 с.

${ }^{2}$ Академічна доброчесність: проблеми дотримання та пріоритети поширення серед молодих вчених : колект. монографія / Артюхов А. та ін. ; за заг. ред. Н. Г. Сорокіної, А. Є. Артюхова, І. О. Дегтярьової. Дніпро : ДРІДУ НАДУ, 2017. 168 с.

3 Академічна доброчесність студента як чинник формування громадянського суспільства : матеріали III Міжнар. наук.-практ. конф. студентів та молодих учених, 1-2 берез. 2018 р. / Вищ. держ. навч. закл. України
} 
The article aims to analyse the essence of the concept "academic integrity" with reference to the current legislation (in particular, the Law of Ukraine dated 05.09.2017 "On Education") and to find out the features of statutory regulation of academic integrity as one of the elements of the system of education quality assurance.

\section{Statutory definition and etymology of the concept "academic integrity"}

It is worth pointing out that the Law of Ukraine dated 05.09.2017 "On Education" consolidated the concept "academic integrity" at the statutory level for the first time, because the Law of Ukraine dated 23.05.1991 "On Education"5 (repealed) had not included such a concept at all. Thus, according to the legal definition, academic integrity is a set of ethical principles and rules defined by the law, which should be followed by the actors of an educational process during studying, teaching and carrying out scholarly (creative) endeavor to ensure the confidence in the outcomes of learning and/or scientific (creative) achievements. The Law of Ukraine dated 01.07.2014 "On Education" also fixes the similar definition - the Law was amended in the light of the adoption of the Law of Ukraine "On Education". T. Finikov emphasizes that current classic definition of "academic integrity" is based on the combination of the following fundamental virtues: honesty, trust, fairness, respect, responsibility, and in 2013, it was amended by new sixth virtue - courage ${ }^{7}$. Etymologically, the concept "academic integrity" is composed of the combination of two words: "academic", which dictionaries render as 1) related to academy; performed by it; 2) educational; 3) purely theoretical, abstract; one without practical value, book-learned; 4) one which adheres to established traditions in the arts $^{8}$, and "integrity" - property in the terms of "virtuous"; who lives honestly, follows all moral rules; the manifestation of honesty, morality ${ }^{9}$. V. Khmarskyi, studying American

${ }^{4}$ Про освіту : Закон України від 05.09.2017 р. Відомості Верховної Ради (ВВР). 2017. № 38-39. Ст. 380.

${ }^{5}$ Про освіту : Закон України від 23.05.1991 р. (втратив чинність на підставі Закону № 2145-VIII від 05.09.2017 р.). Відомості Верховної Ради УРСР (ВВР). 1991. № 34. Ст. 451.

${ }^{6}$ Про вищу освіту: Закон України від 01.07.2014 р. Відомості Верховної Ради (ВВР). 2014. № 37-38. Ст. 2004.

${ }^{7}$ Академічна чесність як основа сталого розвитку університету / Міжнарод. благод. Фонд "Міжнарод. фонд. дослідж. освіт. Політики"; за заг. ред. Т. В. Фінікова, А. Є. Артюхова. Київ : Таксон, 2016. С. 11.

${ }^{8}$ Словник української мови в 11 тт. / АН УРСР. Інститут мовознавства; за ред. І. К. Білодіда. Київ : Наукова думка, 1970-1980. Т. 1, 1970. С. 25.

${ }^{9}$ Словник української мови в 11 тт. / АН УРСР. Інститут мовознавства; за ред. І. К. Білодіда. Київ : Наукова думка, 1970-1980. Т. 2, 1971. С. 326. 
experience of academic integrity, also pays attention to the essence of conceptual equivalent - "academic integrity". He notes that "academic" derives from "Academia", known since antiquity as the name of a school where Plato gave lectures in IV century BC. A corresponding adjective is used to denote one that relates to the top level in the realm of sciences or arts - academic level, academic theater etc. as well as a synonym for the concept "educational" - academic group, academic leave, etc.; "integrity" derives from the Late Latin "integer" (whole number), "integrare" (to complete) or "integritas" (integrality). The vast majority of words with this root refer to mathematics, and only the term "integrity" is an exception since it puts "moral purity", "honesty" first from three interpretations, and then - "integrality, completeness" and "quality or state of inviolacy"10. Thus, one can take up the position that "academic integrity" is connected with "educational and scientific integrity" etymologically.

Taking into account the regulatory definition of academic integrity as well as its etymological content, it is possible to formulate a range of characteristic features peculiar to such a concept; they are as follows:

- a complex nature - a specific combination of the moral and legal fundamentals that is expressed in a set of ethical principles and statutory rules;

- availability of the special actor - participants of the educational process (they are represented by the degree-seeking students; academic and research staff; parents of degree-seeking students; individuals conducting educational activities; other individuals which are stipulated by the special laws and involved in the educational process under the procedure outlined in the education institution);

- well-defined application scope - in the process of training, teaching and carrying out educational (creative) activities;

- a special aim, namely - supporting confidence in the training outcomes and/or scientific (creative) achievements.

I. Dehtiarova, studying the influence of academic integrity on the institutional practice of Ukrainian higher education, marks that academic integrity may be discussed within four dimensions:

- individual - at the level of a specific individual - a student, lecturer, researcher, senior, when the emphasis is placed on personal and professional ethics of an individual and his/her values, observance of moral principles and professional code of conduct, building of reputation and respect in the academic environment;

10 Академічна чесність як основа сталого розвитку університету / Міжнарод. благод. Фонд "Міжнарод. фонд. дослідж. освіт. Політики”; за заг. ред. Т. В. Фінікова, А. Є. Артюхова. Київ : Таксон, 2016. С. 54-55. 
- institutional - tolerating/non-tolerating of such phenomena at the level of a particular higher education institution or the scientific establishment, creation of some regulatory preconditions to cultivate academic integrity at the institutional level, introduce these principles in the process of training, evaluating and rating of academic staff, as well as in personnel policy;

- system-based - consolidation of the principles of academic integrity within the system of higher education and science, in particular, through the legitimization of relevant points in statutory acts which are a legal framework for its functioning;

- collegiate - at the level of a broadly defined academic environment as a formal/non-formal union of participants of educational and scientific activity (students, postgraduates, researchers, lecturers, administrators et al. $)^{11}$. Thus, it can be argued that simultaneous observance of academic integrity at all these levels (at the level of the individual, institution, academic environment and the legislation) will make it possible to suggest about multilevel assurance of education quality and its improvement.

\section{Academic integrity as an inherent element of education quality}

Considering academic integrity as an inherent element of education quality, it stands to mention that education quality should be comprehended as a correspondence of training outcomes with the statutory requirements, a relevant education standard and/or an agreement for the provision of educational services. In accordance with the statutory provisions, the system of education quality assurance has three components at the structural level:

1) quality assurance system in the educational establishments (internal system of education quality assurance);

2) system of external assurance of education quality;

3) quality assurance system in the activities of control bodies and establishments which carry out an external assurance of education quality.

In view of the set of the above three components, the system and mechanisms ensuring academic integrity is an element of the first component of the system of education quality assurance (internal).

The legislation envisages the list of measures which are designed to adhere to academic integrity. In other words, there is a statutory set of actions which indicate an appropriate use of the principles of academic integrity. The following measures are grouped according to the subjects that

11 Академічна чесність як основа сталого розвитку університету / Міжнарод. благод. Фонд “Міжнарод. фонд. дослідж. освіт. Політики”; за заг. ред. Т. В. Фінікова, А. Є. Артюхова. Київ : Таксон, 2016. С. 199-200. 
apply them - individually for academic and research staff and degreeseeking students:

\begin{tabular}{|l|l|}
\hline \multicolumn{2}{|c|}{ Measures which are designed to adhere to academic integrity } \\
\hline for academic and research staff & for degree-seeking students \\
\hline - references to data sources in case & - an independent exercise of \\
of the use of ideas, developments, & academic assignments, tasks of the \\
statements, information; & current and final assessment of \\
- compliance with copyright law and & training results (this requirement is \\
related rights; & applied for individuals with special \\
- provision of reliable information & educational needs taking into \\
on methods and research findings, & account their individual needs and \\
references and own teaching & capabilities); \\
(academic, creative) activities; & - references to data sources in case \\
- control over the observance of & of the use of ideas, developments, \\
academic integrity by the degree- & statements, information; \\
seeking students; & -compliance with copyright law and \\
- an impartial assessment of training & related rights; \\
results. & - provision of reliable information \\
& on the results of their learning \\
& (academic, creative) activities, \\
& research methods and references. \\
\hline
\end{tabular}

A feature of legislative consolidation of the provisions on academic integrity is the regulatory determination of a detailed list of violations of academic integrity with defining the content of each of them, in particular:

- academic plagiarism - a publication (partially or in full) of scientific (creative) results obtained by others as the results of own research (creativity) and / or reproduction of published texts (published art pieces) of other authors without affiliation;

- self-plagiarism - a publication (partially or in full) of own previously published scientific findings as new ones;

- fake - the fabrication of data or facts used in the educational process or research;

- counterfeit - conscious alteration or modification of available data relating to the educational process or research;

- copying - execution of paperwork involving external sources of information, expect ones permitted for use, in particular, when evaluating learning outcomes;

- dishonesty - provision of deliberately false information about own educational (scientific, creative) activity or organization of the educational 
process; the forms of cheat include, in particular, academic plagiarism, selfplagiarism, fake, counterfeit and copying;

- corrupt practices - provision (reception) of a participant of the educational process, or a proposal of provision (reception), with money, property, services, benefits or any other rewards of a tangible or intangible nature to score an unlawful advantage in the educational process;

- biased assessment - intended overestimation or under-estimation of assessment of degree-seeking students.

It is worthwhile noting that the Law of Ukraine dated 05.09.2017 "On Education" introduced one more innovation in the form of responsibility - academic one. However, the Law didn't define the content of the concept "academic responsibility" but some aspects and general rules of its application were regulated.

Thus, the legislation provides for the general rule that types of academic responsibility (including additional and/or detailed) of the participants of the educational process for specific violations of academic integrity are defined by the special laws and/or internal provisions of the educational establishment, which should be approved (agreed) by the head collegiate authority of educational establishment in the context of their responsibility. The procedure for detection and determination of the acts infringing academic dignity is also defined by the authorized administrative collegiate body of the educational establishment. For example, N. Maslova, analyzing academic freedom and academic responsibility, considers the essence of academic responsibility through a broader lens crossing the line of legal one and names it as "a kind of social responsibility" which includes three levels: 1) responsibility to yourself; 2) responsibility to other actors of academic community 3 ) responsibility to the state and society; at the same time, the first level of academic responsibility has exclusively moral nature; the second level can have a moral, collegiate or legal nature, and the third level is purely legal ${ }^{12}$.

The legislation stipulates the forms and types of academic responsibility depending on a violator: the special laws (among which there are the Laws of Ukraine "On Preschool Education", "On General Secondary Education", "On Non-Formal Education", On Vocational Education", "On Higher Education") define them for higher education institutions; the Law of Ukraine dated 05.09.2017 "On Education" - for academic and research staff, degree-seeking students, in particular:

12 Маслова Н. Г. Академічна свобода і академічна відповідальність. Науковий вісник Ужгородського національного університету. Серія право. 2017. Вип. 43. Т. 1. C. $75-76$. 


\begin{tabular}{|l|l|}
\hline \multicolumn{2}{|c|}{ Consequences of the application of academic responsibility } \\
\hline for academic and research staff & for degree-seeking students \\
\hline - rejection of conferring an & - repeated grading (module test, \\
academic degree or academic rank; & exam, final test); \\
- deprivation of the awarded & - repeated completion of a relevant \\
academic degree (educative- & educational component of the \\
creative) degree or academic rank; & academic program; \\
- rejection of conferring or & - expulsion from the educational \\
deprivation of pedagogical degree, & establishment (expect individuals \\
qualification category; & who are gaining second-level \\
- deprivation of the right to take & education); \\
part in the activities or hold posts & - deprivation of an academic \\
ascertained by the law. & scholarship; \\
& - deprivation of tuition benefits \\
& provided by the educational \\
& establishment. \\
\hline
\end{tabular}

Taking into account seriousness of the consequences for a person, who has violated the principles of academic integrity, it is worth emphasizing the need for full, comprehensive, impartial proceedings in a case against the person who is held to academic responsibility. Moreover, in-depth consolidation of all procedural aspects of bringing to academic responsibility (with terms, stages, actors, appeal procedures, etc.) at the regulatory level is urgent. The Law of Ukraine dated 05.09.2017 "On Education" attaches the rights of individuals who are under investigation concerning academic integrity violation, specifically:

- to have a look at verification materials on the finding of the violation of academic integrity, to comment on them;

- to provide oral and written pleadings personally or by proxy or to refuse to give any explanations, to participate in the study of evidence of academic integrity violation;

- to have notice of the date, time and place and be present when considering the issue of determination of academic integrity violation and bringing him/her to academic responsibility;

- to appeal against the decision to bring to academic responsibility to the body authorized to consider appeals or to court.

It also should be noted that academic integrity violation is not only a reason for bringing a person to academic responsibility but also for other types of liability on the grounds and in the manner prescribed by law. Put that in context, violation of academic integrity may be a reason for bringing 
the person to disciplinary responsibility (Arts. 147-152 of the Labour Code of Ukraine), civil responsibility (general rules of compensation of damage are defined by Section 82 of the Civil Code of Ukraine), administrative responsibility (for example, Art. 51-2 of the Code on Administrative Offences of Ukraine "Infringement of the rights to intellectual property"), criminal responsibility (for example, Art. 176 of the Criminal Code of Ukraine "Infringement of copyright and related rights").

\section{CONCLUSIONS}

Therefore, it should be marked positively that there is a necessary regulatory basis for defining the concept of academic integrity and the general principles of its application at the legal level. Features which characterize academic integrity include: a complex nature (specific combination of the moral and legal fundamentals that is expressed in a set of ethical principles and statutory rules); availability of a special actor participants of the educational process (degree-seeking students; academic and research staff; parents of degree-seeking students; individuals conducting educational activities; other individuals which are stipulated by the special laws and involved in the educational process under the procedure outlined in the education institution; well-defined application scope - in the process of training, teaching and carrying out educational (creative) activities; a special aim, namely - achieving confidence in the training outcomes and/or scientific (creative) achievements. A person may be brought to disciplinary, civil, administrative or criminal responsibility for the violation of rules of academic integrity. Moreover, there are measures of a new type of responsibility ascertained by the law - academic.

\section{SUMMARY}

The article is devoted to the determination of the essence of the concept "academic integrity" based on the current legislation and clarification of the peculiarities of statutory regulation of academic integrity as one of the elements of the system of education quality assurance. The author's list of features peculiar to academic integrity is proposed. The list of measures which are designed to adhere to academic integrity is determined. A new type of responsibility for breaking the principles of academic integrity is analyzed.

\section{REFERENCES}

1. Академічна чесність як основа сталого розвитку університету / Міжнарод. благод. Фонд "Міжнарод. фонд. дослідж. освіт. Політики"; за заг. ред. Т.В.Фінікова, А.С.Артюхова. Київ : Таксон, 2016. 234 с. 
2. Академічна доброчесність: проблеми дотримання та пріоритети поширення серед молодих вчених : колект. монографія / Артюхов А. та ін. ; за заг. ред. Н. Г. Сорокіної, А. С. Артюхова, І. О. Дегтярьової. Дніпро : ДРІДУ НАДУ, 2017. 168 с.

3. Академічна доброчесність студента як чинник формування громадянського суспільства : матеріали III Міжнар. наук.-практ. конф. студентів та молодих учених, 1-2 берез. 2018 р. / Вищ. держ. навч. закл. України “Буковин. держ. мед. ун-т”, Студент. рада БДМУ ; [відп. ред. Н. І. Зорій]. Чернівці : БДМУ, 2018. 239 с.

4. Про освіту : Закон України від 05.09.2017 р. Відомості Верховної Ради (ВВР). 2017. № 38-39. Ст. 380.

5. Про освіту : Закон України від 23.05.1991 р. (втратив чинність на підставі Закону № 2145-VIII від 05.09.2017 р.). Відомості Верховної Ради УРСР (ВВР). 1991. № 34. Ст. 451.

6. Про вищу освіту: Закон України від 01.07.2014 р. Відомості Верховної Ради (ВВР). 2014. № 37-38. Ст. 2004.

7. Словник української мови в 11 тт. / АН УРСР. Інститут мовознавства; за ред. І. К. Білодіда. Київ : Наукова думка, 1970-1980. T. 1, 1970. 799 c.

8. Словник української мови в 11 тт. / АН УРСР. Інститут мовознавства; за ред. І. К. Білодіда. Київ : Наукова думка, 1970-1980. T. 2, 1971. $550 \mathrm{c}$.

9. Маслова Н. Г. Академічна свобода і академічна відповідальність. Науковий вісник Ужгородського національного університету. Серія право. 2017. Вип. 43. Т. 1. С. 72-76.

\section{Information about the author:} Tytska Ya. O., Senior Lecturer at the Department of Theory and History of State and Law,

International Humanitarian University 33, Fontanska Road str., Odessa, 65009, Ukraine 